\title{
Rate Determination of Nitrogen and Phosphorus Fertilizers for Green Maize Under Irrigation
}

\author{
Abebe Getu* Abreham Teshager Samuel Adissie \\ Sirinka Agricultural Research Center, P.O.Box 74, Woldia, Ethiopia
}

\begin{abstract}
A study was conducted on a research station at Kobo sub-center of Sirinka Agricultural research Center for two years to determine the optimum rates of $\mathrm{N}$ and $\mathrm{P}$ fertilizers for green maize production under irrigation in KoboGirana irrigation valley. Four levels of $\mathrm{N}\left(0,46,92\right.$ and $\left.138 \mathrm{~kg} \mathrm{~N} \mathrm{ha}^{-1}\right)$ with three levels of $\mathrm{P}$ fertilizer $(0,23$ and $\left.46 \mathrm{~kg} \mathrm{P}_{2} \mathrm{O}_{5} \mathrm{ha}^{-1}\right)$ were factorially combined and laid in RCBD design with three replications. A uniform irrigation water depth and interval was applied to all plots based on maize's irrigation water requirement determined for the area. The crop was irrigated a total amount of $500 \mathrm{~mm}$ irrigation water at 7 days interval starting from the development stage. Phosphorus fertilizer was applied all at planting. While, $\mathrm{N}$ fertilizer was applied in split, $1 / 3$ at planting, $1 / 3$ at knee height and $1 / 3$ at tasseling stage. The result shows that there was no significant $(p>0.05)$ interaction of $\mathrm{N}$ and $\mathrm{P}$ fertilizers on the cob yield, cob number, cob length and cob diameter of green maize. However, the main effect of $\mathrm{N}$ fertilizer had significant $(\mathrm{p} \leq 0.05)$ effect on the cob yield, cob number, cob length and cob diameter of green maize. The main effect of application of $P$ fertilizer had insignificant $(p>0.05)$ effect on the cob yield of green maize, which is attributable to the medium to high levels of Olsen's extractable available $\mathrm{P}$ in bottom valleys of alluvial soils of Kobo where the study site laid. The highest cob number (51556) and cob weight (12.0 t ha-1) was recorded from application of $138 \mathrm{~kg} \mathrm{~N} \mathrm{ha}^{-1}$ followed with statistically insignificant $(p>0.05)$ difference by the cob number (49020) and cob weight $\left(11.1 \mathrm{t} \mathrm{ha}^{-1}\right)$ obtained from application of $92 \mathrm{~kg} \mathrm{~N} \mathrm{ha}^{-1}$. The partial budget and the sensitivity analysis result considering $15 \%$ possible price fluctuation show that the highest marginal rate return of $421.7 \%$ was obtained from application of $92 \mathrm{~kg} \mathrm{~N} \mathrm{ha}^{-1}$. While, the lowest marginal rate return of $378.8 \%$ was recorded from application $138 \mathrm{~kg} \mathrm{~N} \mathrm{ha}^{-1}$. Therefore, application of $92 \mathrm{~kg} \mathrm{~N} \mathrm{ha}^{-1}$ is recommended for maximum and economic return of green maize production under irrigation in Kobo valley.
\end{abstract}

Keywords: Green maize, kobo, irrigation, nitrogen, phosphorus.

DOI: $10.7176 / \mathrm{JNSR} / 10-3-03$

Publication date: February $29^{\text {th }} 2020$

\section{Introduction}

Low soil fertility is among the major factors limiting crop production and productivity in Ethiopia. This is common in many tropical cropping systems where fertilizer use is low and little or no agricultural residues are returned to the soil for maintaining soil fertility. Besides, long aged continuous cultivation with nutrientdepleting crops and complete removal of crop residues from farmlands and absence of crop rotation result in irreversible nutrient mining by plant uptake (Heluf, 2005). As a consequence of these and intensive surface soil erosion in the Ethiopian highlands, declining soil fertility is a fundamental impediment to agricultural development and the major reason for the slow growth rate in food production and food insecurity both at household and national levels.

Hence, to increase crop productivity, the depleted soil plant nutrients should be replenished with chemical and organic fertilizers. Use of chemical fertilizers has been proved to significantly increase productivity of crops in Eastern Amhara (Yared et al., 2003). Accordingly, different fertilizer recommendations were made available for most cultivated crops in major agro-ecologies of the country. However, most of the trials were designed and recommended for rain fed conditions. However, irrigation condition is different from rain fed condition in water distribution and crop water use efficiency (Tilahun et al., 2011 and Zhang et al., 1998). Plant nutrient uptake and use efficiency are also variable in rain fed vs irrigation conditions since root density and soil moisture level are highly affected (Drechsel et al., 2015).

Kobo-Girana valley has a high irrigation potential, which accounts 47.7 and $5.5 \%$ of irrigable land in North Wollo Zone and in Amhara Region, respectively (Birhan et al., 2014). Due to its erratic nature and late onset and early offset of rain fall during the main season and recurrent drought, crop production under irrigation is crucial to insure food security in the area.

Maize is one of food crops which are promising to meet food security and it is one of the major crops produced under irrigation in Kobo-Girana irrigation valley (Tsedeke et al., 2015). Green maize production is one of market oriented and preferred product in local market in the area. But, its productivity is much below the production potential due to poor soil fertility and low input utilization. Economically and agronomically optimum irrigation water requirement and irrigation schedule for green maize production was determined for Kobo district. However, there is no economic and agronomic optimal fertilizer recommendations for green 
maize production under irrigation in Kobo-Girana valley. Therefore, taking these premises in to account, a study was conducted to determine optimum rates of nitrogen and phosphorus fertilizers for green maize production under irrigation in Kobo-Girana irrigation area.

\section{Materials and Methods \\ Site Description}

The study was conducted for two years from 2013 - 2014 in Kobo irrigation study site of Sirinka Agricultural Research Center. The study area, Kobo Irrigation scheme, is situated at an altitude of 1450 meters above sea level with annual rainfall, min. and max. temperature of $650 \mathrm{~mm}, 16$ and $29{ }^{\circ} \mathrm{C}$, respectively. The dominant soil types in the area are alluvial and eutric Vertisols. Some of the soil physical and chemical properties of the surface soil is shown in the table below (Table 1).

Table 1. Some physical and chemical characteristics of the study site

\begin{tabular}{ll}
\hline Parameter & Values \\
\hline $\mathrm{pH}\left(\mathrm{H}_{2} \mathrm{O}\right)$ & $6.7-7.8$ \\
$\mathrm{OM}(\%)$ & $2.0-3.0$ \\
Total N. (\%) & $0.08-0.10$ \\
Avail. P (Olsen) & $12-14 \mathrm{mg} \mathrm{kg}^{-1}$ \\
Texture & $45 \%$ Clay, 30\% Silt, 25\% Sand \\
$\left.\mathrm{CEC}(\mathrm{cmol} \mathrm{kg})^{-1}\right)$ & $28-36$ \\
\hline
\end{tabular}

\section{Experimental Procedures}

The study comprised four levels of $\mathrm{N}$ fertilizer $\left(0,46,92\right.$ and $\left.138 \mathrm{~kg} \mathrm{ha}^{-1}\right)$ and three levels of P fertilizer $(0,23$ and $\left.46 \mathrm{~kg} \mathrm{P}_{2} \mathrm{O}_{5} \mathrm{ha}^{-1}\right)$. These fertilizer levels of $\mathrm{N}$ and $\mathrm{P}$ were combined in a complete factorial arrangement and were laid in RCBD with three replications. Nitrogen fertilizer was applied in split at three growth stages of the test crop; one-third at planting, one-third at knee height and one-third at tasseling stages. While, the P fertilizer, in TSP (Triple Super Phosphate) form, was applied all at planting. Melkassa-2 maize variety was used as a test crop. The spacing between rows and plants were 75 and $30 \mathrm{~cm}$, respectively. The experimental plots had an area of $3 \mathrm{~m} \times 3 \mathrm{~m}$. The net harvestable plot size was $1.5 \mathrm{~m} \times 3 \mathrm{~m}$. Irrigation was applied with siphon at 7 days interval starting from the development stage with a total irrigation depth of $500 \mathrm{~mm}$.

\section{Results and Discussions}

\subsection{Effect of $N$ and $P$ fertilizers on the yield of maize}

The first and second year data statistical analysis showed that there was no significant $(\mathrm{P}>0.05)$ interaction effect of $\mathrm{N}$ and $\mathrm{P}$ fertilizers on marketable yield of green maize. Similarly, the main effect of P fertilizer did not significantly affect the yield of green maize in both experimental years. This might be attributed to the existing medium to optimum levels of available phosphorus in the soil as elucidated in Table 1 which resulted in insignificant yield response to the application of $\mathrm{P}$ fertilizer. However, there was a significant $(\mathrm{P} \leq 0.01)$ effect of application of $\mathrm{N}$ fertilizer on the marketable cob yield, cob number and cob length of green maize (Table 2).

Table 2. Main effects of $\mathrm{N}$ and $\mathrm{P}$ fertilizers on the cob yield and related traits of green maize in 2013

\begin{tabular}{|c|c|c|c|c|}
\hline $\begin{array}{l}\text { N rates } \\
\left(\mathrm{kg} \mathrm{ha}^{-1}\right)\end{array}$ & Cob number & $\begin{array}{c}\text { Marketable cob wt. } \\
\left(\mathrm{kg} \mathrm{ha}^{-1}\right)\end{array}$ & Cob length $(\mathrm{cm})$ & Cob diameter $(\mathrm{cm})$ \\
\hline 0 & $40000 \mathrm{~b}$ & $9114.7 \mathrm{c}$ & $14.4 \mathrm{~b}$ & 4.4 \\
\hline 46 & $47366 a$ & $11557 \mathrm{~b}$ & $15.6 \mathrm{a}$ & 4.4 \\
\hline 92 & $48889 a$ & $12859.8 \mathrm{a}$ & $15.6 \mathrm{a}$ & 4.4 \\
\hline 138 & $50000 \mathrm{a}$ & $13277.4 \mathrm{a}$ & $15.4 \mathrm{a}$ & 4.5 \\
\hline GM & 46364.9 & 11621.8 & 15.2 & 4.4 \\
\hline CV (\%) & 6.5 & 9.4 & 5 & 3.3 \\
\hline LSD (0.05) & 3131.1 & 1109.5 & 0.74 & ns \\
\hline \multicolumn{5}{|l|}{$\begin{array}{c}\text { P rates } \\
\left(\mathrm{kg} \mathrm{P}_{2} \mathrm{O}_{5} \mathrm{ha}^{-1}\right)\end{array}$} \\
\hline $\mathbf{0}$ & 45761 & 11327.8 & 14.9033 & 4.38333 \\
\hline 23 & 46465 & 11627.8 & 15.3337 & 4.46167 \\
\hline 46 & 46869 & 11885.9 & 15.4476 & 4.40583 \\
\hline LSD (0.05) & NS & NS & NS & NS \\
\hline
\end{tabular}

The significant response to the application of $\mathrm{N}$ fertilizer was due to the low level of total $\mathrm{N}$ in the surface soil of the study site.

In both experimental years, cob number was significantly increased by application of nitrogen fertilizer. This is due to the effect of $\mathrm{N}$ fertilizer in increasing cob number per plant (Moraditochaee et al., 2012). In 
contrast, cob diameter was not significantly affected by application of $\mathrm{N}$ fertilizer. Similar result was reported by Karasu (2012). .

Table 3. Main effects of $\mathrm{N}$ and $\mathrm{P}$ fertilizers on the cob yield and related traits of green maize in 2014

\begin{tabular}{|c|c|c|c|c|}
\hline $\begin{array}{l}\text { N rates } \\
\left(\mathrm{kg} \mathrm{ha}^{-1}\right)\end{array}$ & Cob number & $\begin{array}{c}\text { Marketable cob wt. } \\
\left(\mathrm{kg} \mathrm{ha}^{-1}\right)\end{array}$ & Cob length (cm) & Cob diameter $(\mathrm{cm})$ \\
\hline 0 & $45115 b$ & $7436.0 \mathrm{c}$ & 13.1 & 4.5 \\
\hline 46 & $45158 b$ & $8962.4 b$ & 13.7 & 4.7 \\
\hline 92 & $49136 \mathrm{ab}$ & $9546.4 \mathrm{ab}$ & 13.9 & 4.7 \\
\hline 138 & $53333 a$ & $10486.8 \mathrm{a}$ & 13.3 & 4.6 \\
\hline GM & 48055.6 & 9026.8 & 13.5 & 4.6 \\
\hline CV (\%) & 11.7 & 16.0 & 5.0 & 6.2 \\
\hline LSD & 5935.3 & 1472.5 & $0.7 \mathrm{~ns}$ & $0.3 \mathrm{~ns}$ \\
\hline \multicolumn{5}{|l|}{$\begin{array}{c}\text { P rates } \\
\left(\mathrm{kg} \mathrm{P}_{2} \mathrm{O}_{5} \mathrm{ha}^{-1}\right)\end{array}$} \\
\hline 0 & 51331 & 9485.9 & 13.5 & 4.625 \\
\hline 23 & 46465 & 8634.3 & 13.3 & 4.5667 \\
\hline 46 & 47058 & 9036.8 & 13.7 & 4.725 \\
\hline GM & 48055.6 & 9026.8 & 13.5 & 4.6 \\
\hline CV $(\%)$ & 11.7 & 16.0 & 5.0 & 6.2 \\
\hline $\operatorname{LSD}(\alpha=0.05)$ & $5136.9 \mathrm{~ns}$ & 1272.4 & $0.58 n s$ & $0.24 \mathrm{~ns}$ \\
\hline
\end{tabular}

Similar to the individual year analysis results, the combined analysis of the two experimental years indicated that only the main effect of $\mathrm{N}$ fertilizer significantly affected the yield of green maize (Table 4). This is accounted for low level of total nitrogen and optimum phosphorus level in the surface soil of the study site (Table 1). In addition, the significant yield response to the increasing levels of $\mathrm{N}$ fertilizer might also be due to the increasing levels of $\mathrm{N}$ uptake by the test crop due to the increasing soil moisture created by the optimum irrigation applied (Dijkstra and Cheng, 2008). However, the increment was not significant beyond application of $92 \mathrm{Kg} \mathrm{N} \mathrm{ha}^{-1}$. Cob length was significantly increased with application of $\mathrm{N}$ up $46 \mathrm{~kg} \mathrm{~N} \mathrm{ha-1}$. The highest cob number of 51556 was obtained from application of $138 \mathrm{~kg} \mathrm{~N} \mathrm{ha}^{-1}$, while the lowest cob number of 49020 was measured from the control treatment. This might be from the importance of $\mathrm{N}$ in increasing cob number per plant (Moraditochaee et.al, 2012).

Similar to cob number, the highest marketable cob weight of $11975.1 \mathrm{~kg} \mathrm{ha}^{-1}$ was recorded from application of $138 \mathrm{~kg} \mathrm{~N} \mathrm{ha}^{-1}$ and the lowest $8275.4 \mathrm{~kg} \mathrm{ha}^{-1}$ was measured from non nitrogen fertilized plot. This is justifiable from the fact that $\mathrm{N}$ is important in grain filling stage and increasing its level eventually lead to increase seed weight, number of rows in a cob and number of seed per row within a cob (Alimohammadi et al., 2011; Hejazi and Sleymani, 2014). Application of 138 and $96 \mathrm{~kg} \mathrm{~N}^{-1}$ gave cob number and marketable cob yield advantages of $22.1 \%$ and $44.7 \%$; and $16.1 \%$ and $34.2 \%$, respectively over the control treatment.

Table 4. Combined analysis over years of the main effects of $\mathrm{N}$ and $\mathrm{P}$ fertilizers on the cob yield and related parameters of green maize

\begin{tabular}{|c|c|c|c|c|}
\hline $\begin{array}{l}\text { N rates } \\
\left(\mathrm{kg} \mathrm{ha}^{-1}\right)\end{array}$ & Cob number & $\begin{array}{c}\text { Marketable cob wt. } \\
\left(\mathrm{kg} \mathrm{ha}^{-1}\right)\end{array}$ & Cob length $(\mathrm{cm})$ & Cob diameter $(\mathrm{cm})$ \\
\hline 0 & $42238 \mathrm{c}$ & $8275.4 \mathrm{c}$ & $13.8 \mathrm{~b}$ & 4.5 \\
\hline 46 & $46197 b$ & $10259.7 b$ & $14.6 \mathrm{a}$ & 4.6 \\
\hline 92 & $49020 \mathrm{ab}$ & $11105.6 \mathrm{ab}$ & $14.7 \mathrm{a}$ & 4.5 \\
\hline 138 & $51556 \mathrm{a}$ & $11975.1 \mathrm{a}$ & $14.3 \mathrm{a}$ & 4.6 \\
\hline GM & 47197.2 & 10324.3 & 14.4 & 4.5 \\
\hline CV (\%) & 9.8 & 12.2 & 4.9 & 5.0 \\
\hline LSD (0.05) & 3271.0 & 871.4 & 0.5 & $0.2 \mathrm{~ns}$ \\
\hline \multicolumn{5}{|l|}{$\begin{array}{c}\text { P rates } \\
\left(\text { kg } \mathrm{P}_{2} \mathrm{O}_{5} \mathrm{ha}^{-1}\right)\end{array}$} \\
\hline 0 & 48267 & 10450.7 & 14.2 & 4.5 \\
\hline 23 & 46465 & 10065.9 & 14.3 & 4.5 \\
\hline 46 & 46967 & 10461.3 & 14.6 & 4.6 \\
\hline LSD (0.05) & ns & ns & ns & ns \\
\hline
\end{tabular}

\subsection{Correlation of yields of green maize with the nitrogen}

As it is depicted in figure 1 below, there was a significant correlation between cob number and cob weight and application of $\mathrm{N}$ levels in both experimental years. This confirms the importance of $\mathrm{N}$ in increasing cob number 
and cob weight. Similar results of significant correlation of cob number with nitrogen levels was reported by Inammullah et al., (2011).

a)

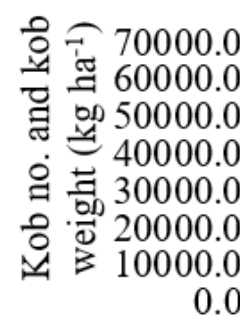

0.0

\section{Nitrogen levels $\left(\mathrm{kg} \mathrm{ha}^{-1}\right)$}

Kob no.
Kob weight b)

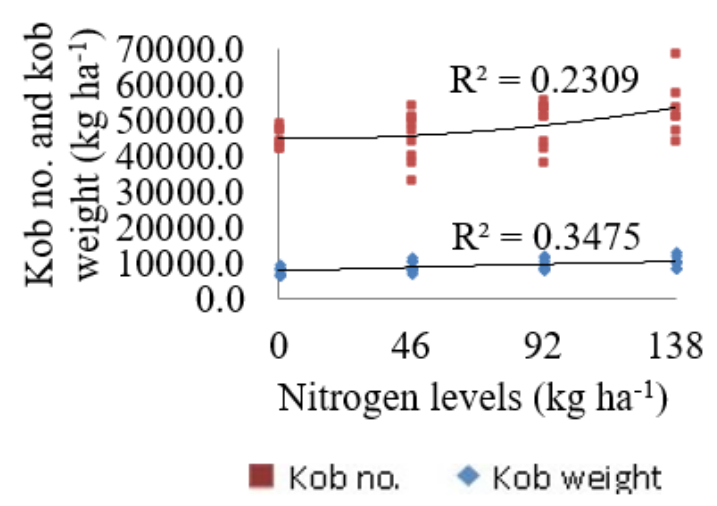

c)

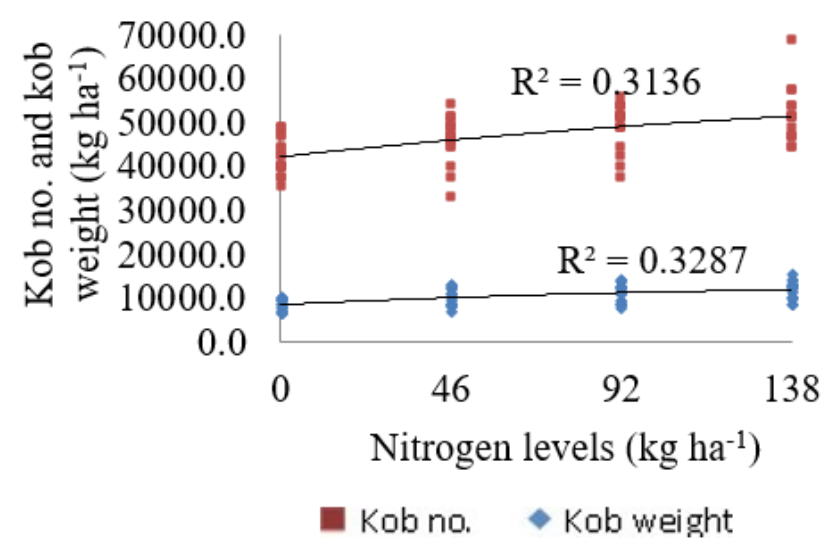

Figure 1: shows the correlation of kob no and kob weight of green maize as the level of nitrogen increases from 0 to $138 \mathrm{~kg} \mathrm{ha}^{-1}$ in a) 2005 , b) 2006 and c) pooled over years

\subsection{Economic Profitability of the Fertilizer rates}

The partial budget analysis, as shown in the table below, of the green maize yield value added by the application of each rate of nitrogen fertilizer including the labour cost consumed to apply the different rated $\mathrm{N}$ fertilizer showed that the maximum marginal net return was recorded from application of $46 \mathrm{~kg} \mathrm{~N} \mathrm{ha}^{-1}$ followed by application of $92 \mathrm{~kg} \mathrm{~N} \mathrm{ha}^{-1}$. While, the lowest was recorded from application of $138 \mathrm{~kg} \mathrm{~N} \mathrm{ha}^{-1}$. However, the highest marginal rate return of $421.7 \%$ was recorded from application of $92 \mathrm{~kg} \mathrm{~N} \mathrm{ha}^{-1}$, followed by application of $138 \mathrm{~kg} \mathrm{~N} \mathrm{ha}^{-1}$.

Table 5. Partial budget analysis of the $\mathrm{N}$ rates tested in the experiment

\begin{tabular}{ccccccccc}
\hline $\mathbf{N}$ & $\begin{array}{c}\text { Cob } \\
\text { No. }\end{array}$ & $\begin{array}{c}\text { Unit Cob } \\
\text { price }\end{array}$ & $\begin{array}{c}\text { Reven } \\
\text { ue }\end{array}$ & $\begin{array}{c}\text { Production } \\
\text { Cost }\end{array}$ & $\begin{array}{c}\text { Net } \\
\text { Return }\end{array}$ & $\begin{array}{c}\text { Marginal } \\
\text { Cost }\end{array}$ & $\begin{array}{c}\text { Marginal net } \\
\text { return }\end{array}$ & $\begin{array}{c}\text { MRR } \\
(\%)\end{array}$ \\
\hline 0 & 42238 & 2.0 & 84476 & 0 & 84476.0 & - & - & - \\
46 & 46197 & 2.0 & 92394 & 2033.4 & 90360.6 & 2033.4 & 5884.6 & 389.4 \\
92 & 49020 & 2.0 & 98040 & 3372.4 & 94667.6 & 1339.0 & 4307.0 & 421.7 \\
13 & & & 10311 & & & & & \\
8 & 51556 & 2.0 & 2 & 4711.4 & 98400.6 & 1339.0 & 3733.0 & 378.8 \\
\hline
\end{tabular}

Note: $\mathrm{N}$ rate $\left(\mathrm{kg} \mathrm{ha}^{-1}\right)$; All the Unit cob price, Revenue, Production cost, Net return, marginal product, marginal cost and marginal net reurn are in Eth. birr

\subsubsection{Sensitivity Analysis}

The sensitivity analysis was carried out by taking the possible production costs (fertilizers and labour) inflation of $15 \%$ and the possible $15 \%$ deflation of yield costs from the current market price. The sensitivity analysis result, as shown in the table below, showed that variability of variable costs up to $15 \%$ do not affect the profitability of the $\mathrm{N}$ fertilizer rate selected. 
Table 6. Sensitivity analysis of the economic profitability of the $\mathrm{N}$ rates tested in the experiment

\begin{tabular}{cccccccccc}
\hline N rate & $\begin{array}{c}\text { Cob } \\
\text { No }\end{array}$ & $\begin{array}{c}\text { Unit } \\
\text { Cob } \\
\text { price }\end{array}$ & Revenue & $\begin{array}{c}\text { Produc } \\
\text { tion } \\
\text { Cost }\end{array}$ & $\begin{array}{c}\text { Net } \\
\text { Return }\end{array}$ & $\begin{array}{c}\text { Marginal } \\
\text { product }\end{array}$ & $\begin{array}{c}\text { Marginal } \\
\text { Cost }\end{array}$ & $\begin{array}{c}\text { Margin } \\
\text { al net } \\
\text { return }\end{array}$ & $\begin{array}{c}\text { MRR } \\
(\%)\end{array}$ \\
\hline 0 & 42238 & 2.0 & 71804.6 & 0 & 71804.6 & & & & \\
46 & 46197 & 2.0 & 78534.9 & 2338.5 & 76501.5 & 6730.3 & 2338.5 & 4696.9 & 287.9 \\
92 & 49020 & 2.0 & 83334 & 3878.3 & 79961.6 & 4799.1 & 1539.9 & 3460.1 & 311.7 \\
138 & 51556 & 2.0 & 87645.2 & 5418.1 & 82933.8 & 4311.2 & 1539.8 & 2972.2 & 280.0 \\
\hline
\end{tabular}

Note: $\mathrm{N}$ rate $\left(\mathrm{kg} \mathrm{ha}^{-1}\right)$; All the Unit cob price, Revenue, Production cost, Net return, marginal product, marginal cost and marginal net reurn are in Eth. birr

\section{Conclusion and Recommendation}

The data analysis of the study revealed that only the main effect of application of $\mathrm{N}$ fertilizer had a significant effect on the yield of green maize. While, there was no significant yield response to application of $\mathrm{P}$ fertilizer and its interaction with $\mathrm{N}$ fertilizer. This is accounted for the medium to high level of plant available $\mathrm{P}$ and low to medium level of total $\mathrm{N}$ in the surface soil of the study site, as it is attested by the laboratory analysis result. The agronomic and economic optimum rate of $\mathrm{N}$ found out in this study is application of $92 \mathrm{~kg} \mathrm{~N} \mathrm{ha}^{-1}$. Therefore, for maximum and profitable yield return of green maize production under irrigation in Kobo-Girana irrigation area and similar agro-ecologies with similar soil properties, application of $92 \mathrm{~kg} \mathrm{~N} \mathrm{ha}^{-1}$ is recommended. While, application of $\mathrm{P}$ fertilizer is not recommended for green maize production under irrigation in kobo valley.

\section{References}

Tsedeke S.,Abate, B., Menkir, Abebe Wegary, D., \& Kebede, Y. (2015). Factors that transformed maize productivity in Ethiopia. Springer. http://doi.org/10.1007/s12571-015-0488-z.

Alimohammadi, M., Yousefi, M., \& Zandi, P. (2011). Impact of Nitrogen rates on growth and yield attributes of Sweet Corn grown under different Phosphorus levels, 7(10), 201-206.

Dijkstra, F. A., \& Cheng, W. (2008). Increased soil moisture content increases plant N uptake and the abundance of $15 \mathrm{~N}$ in plant biomass. Springer: Plant Soil, 263-271. http://doi.org/10.1007/s11104-007-9477-0.

Drechsel, Pay Heffer, Patrick Magen, Hillel Mikkelsen, Robert Singh, H., \& Wichelns, and D. (2015). Managing water and nutrients to ensure global food security, while sustaining ecosystem services. In Managing Water and Fertilizer for Sustainable Agricultural Intensification (pp. 1-270).

Hejazi, L., \& Soleymani, A. (2014). Effect of different amounts of nitrogen fertilizer on grain yield of forage corn cultivars in Isfahan, 2(3), 608-614.

Heluf Gebrekidan, 2005. Soil and Water Conservation Practices (Tied Ridges and Planting Methods) on Cultivated Lands of Eastern Ethiopian Highlands: Experience of Soil and Water Research Program, Alemaya University. Soil Science Technical Bulletin No. 2. Department of Plant Sciences, AU, Alemaya.

Inamullah, Naveedur Rehman, Nazeer Hussain Shah, Muhammad Arif Siddiq, MuhammadMian, Ishaq Ahmad Mian (2011). Correlations Among Grain Yield and Yield Attributes in Maize Hybrids At Various Nitrogen Levels, Sarhad J.Agriculture, 27(4).

Karasu A.(2012). Effect of Nitrogen Levels on Grain Yield and Some Attributes of Some Hybrid Maize Cultivars (Zea mays indentata Sturt.) Grown for Silage as Second Crop, Bulgarian Journal of Agricultural Science, 18 (No 1) 2012, 42-48.

Moraditochaee, M., Motamed, M. K., Azarpour, E., Danesh, R. K., \& Bozorgi, H. R. (2012). Effects of Nitrogen Fertilizer and Plant Density Management in Corn Farming, 7(2), 133-137.

Birhan T., Tadesse, G., \& Zemedu, L. (2014). Technical efficiency in irrigated small-scale agriculture: Empirical evidence from onion farming in Kobo District of Northeast Ethiopia, 3(May), 35-46.

Tilahun H, E. Teklu, M. Michael, H. F. and S. B. A. (2011). Comparative Performance of Irrigated and Rainfed Agriculture in Ethiopia, 14(2), 235-244.

Yared Assefa, Aweke Mulualem, Belete Berhanu. 2003. Location Specific on farm fertilizer response of ceareals in south wello and North wollo.

Zhang, H., Oweis, T.Y., Garabet, S, P. M. (1998). Water-use efficiency and transpiration efficiency of wheat under rain-fed conditions and supplemental irrigation in a Mediterranean-type environment. Springer Plant and Soil, 201, 295-305. 